\title{
Double outlet right ventricle Cross sectional echocardiographic findings, their anatomical explanation, and surgical relevance
}

\author{
FERGUS J MACARTNEY, MICHAEL L RIGBY, ROBERT H ANDERSON, JAROSLAV \\ STARK, NORMAN H SILVERMAN* \\ From the Department of Paediatric Cardiology, Institute of Child Health; the Thoracic Unit, The Hospital for Sick \\ Children; and the Department of Paediatrics, Cardiothoracic Institute, Brompton Hospital, London
}

SUMmARY The precise method of surgical repair of double outlet right ventricle depends both on the relation of the interventricular communication to the cardiac outlets and on the course and insertion of the atrioventricular valve tension apparatus. It may be difficult to connect the interventricular communication with one or other outlet or both either because the interventricular communication is too far from the outlets or because atrioventricular tension apparatus interposes between them. This study was carried out in order to establish whether these details could be recognised preoperatively using cross sectional echocardiography. Forty two echocardiograms were reviewed retrospectively from patients with double outlet right ventricle, excluding those with atrioventricular septal defects and atrioventricular discordance. Ten further such patients were studied prospectively. The diagnosis was confirmed at open heart surgery in 19 patients. The relation of the great arteries and their outlet tracts to each other and to the interventricular communication was readily and accurately predicted. Four patients (7.7\%) had no infundibular septum. The remaining 48 had such a septum. In $27(52 \%)$ the interventricular communication was overridden by a great artery. In $14(27 \%)$ it was roofed by the ventriculoinfundibular fold, and in $11(21 \%)$ it was confined to the inlet or trabecular septa. The insertion of chordae tendineae limited the possible surgical options in 12 patients (23.1\%) who were distributed unpredictably among the above groups. Four patients had straddling atrioventricular valves. In five, tricuspid tension apparatus inserted into the underside of the infundibular septum and, in two, into the roof of the defect. In one patient the mitral valve inserted into the defect floor. Tricuspid tension apparatus inserted into the floor of the defect in a further nine patients, but this does not compromise surgery. Thus in double outlet right ventricle cross sectional echocardiography can provide unique information necessary for planning of rational surgical management.

Double outlet right ventricle is a condition in which both great arteries are connected completely or predominantly to the right ventricle. There is almost always an associated ventricular septal defect through which blood can escape from the left ventricle. Sev-

Requests for reprints to Professor FJ Macartney, The Hospital for Sick Children, Great Ormond Street, London WCIN 3JH.

$\star$ Present address: Department of Pediatrics, University of California, San Francisco, USA.

Accepted for publication 13 March 1983 eral descriptions of the cross sectional echocardiographic findings have been reported. ${ }^{-8}$

Of key surgical importance in double outlet right ventricle is the relation of the interventricular communication to the great arteries. ${ }^{9-11}$ Cross sectional echocardiography has been shown accurately to predict this relation, 67 but there has been little or no attempt to demonstrate anatomically why this should be so. Furthermore, the key question of the relation between the atrioventricular valves (including their tension apparatus) and the pathway from the interventricular communication to one or other great artery, which profoundly affects the ease with which 
an intraventricular conduit can be inserted, has not been examined other than in a brief communication based on our own case material. ${ }^{12}$ For these reasons we have studied the cross sectional anatomy of double outlet right ventricle, as demonstrated both by echocardiography and at necropsy, concentrating in particular on its effects on surgical repair.

\section{DEFINITIONS OF SEPTAL STRUCTURES AND DEFECTS THEREIN}

In double outlet right ventricle the outlet (infundibular septum), if present, is by definition a right ventricular structure since it separates two outlets committed entirely or predominantly to the right ventricle. In the exceptional circumstance that both arterial valves override the trabecular septum, a small part of the outlet septum might be regarded as being within the left ventricle, but almost always the outlet septum is contained exclusively within the right ventricle. Thus the communication between the right and left ventricle, which we term the interventricular communication, can hardly ever be (and, in the cases reported, never was) roofed by the outlet septum. It is important to distinguish between the interventricular communication thus defined and a "ventricular septal defect," since the latter term may be ambiguous. Fig. 1 illustrates the point in the case of an overriding arterial valve. If the other arterial valve is entirely committed to the right ventricle there are three communications which could potentially be termed the

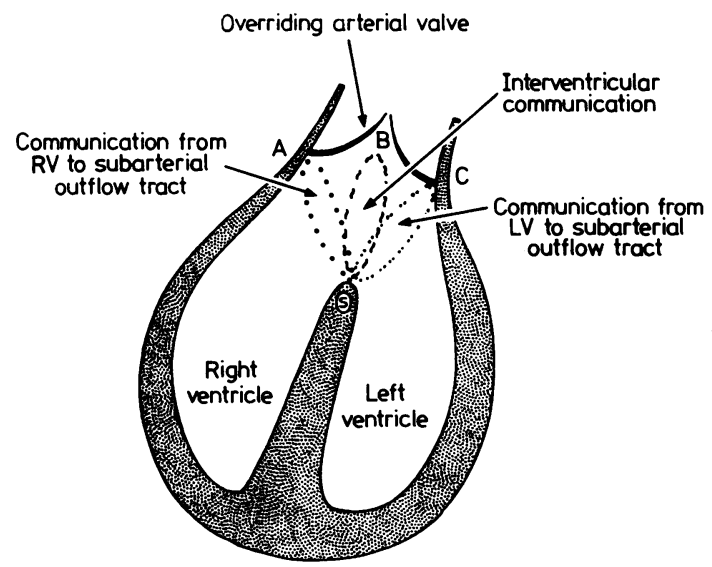

Fig. 1 Diagram showing three communications ( $A S, B S$, and $C S)$, potentially termed the ventricular septal defect, in a patient with overriding of the arterial valves in double outlet right ventricle. $A$, infundibular septum; $B$, coapted leaflets of overriding valve; $C$, ventriculoinfundibular fold or area of arterial-atrioventricular valve fibrosis continuity; $S$, septal crest; $L V$, left ventricle; $R V$, right ventricle. (For a detailed explanation of the definitions of septal structures and defects, see introduction.) ventricular septal defect, all of which are floored by the septal crest (S): the roof of the first is the infundibular septum (A), the roof of the second exists only during ventricular diastole, being the coapted valve leaflets of the overriding valve (B), and the roof of the third is the ventriculoinfundibular fold or the area of arterial-atrioventricular valve fibrosis continuity (C) (Fig. 1). When an arterial valve overrides a defect it is the second of these communications (SB) that is the interventricular communication. From the surgical point of view closure of the second communication is impossible, and closure of the third (SC) would be fatal unless some other exit from the left ventricle were provided. The first objective of surgery is to provide an exclusive route from the interventricular communication to one great artery. This applies wherever the interventricular communication is and in the particular case in Fig. 1 is achieved by closing the communication from the right ventricle to the subarterial outflow tract (SA). If the artery in question were exclusively connected to the right ventricle in such a case it is the third communication (SC) that would be the interventricular communication.

\section{Material and methods}

The records of cross sectional echocardiography, angiocardiography, necropsy, or surgery at either The Hospital for Sick Children or the Brompton Hospital, London, were examined for patients who might have double outlet right ventricle. Those who had not undergone cross sectional echocardiography were excluded. The extant cross sectional echocardiograms were then reviewed by one or two observers who knew only that the patient might have double outlet right ventricle. Patients with overriding arterial valves but without double outlet right ventricle were deliberately included so as to check observer reliability in making the diagnosis. The echocardiograms selected for subsequent analysis were limited to those which in the opinion of at least two independent observers demonstrated double outlet right ventricle with atrioventricular concordance (or atrial isomerism and biventricular atrioventricular connexion with a right hand pattern of ventricular morphology). During the study 10 new patients with double outlet right ventricle were included and evaluated prospectively. Hearts with atrioventricular septal defects and atrioventricular discordance, with their additional malformations at the atrioventricular junction, present particular problems in assessing the ventriculoarterial connexion, so they were set aside to be reported independently at a later date.

Early in the study the only information in some patients on which to base a diagnosis of atrial arrangement (situs) was the connexions of the great 
systemic and pulmonary veins. More recently, the criteria for diagnosing atrial situs proposed by Huhta and colleagues ${ }^{13}$ were used.

The presence of atrioventricular concordance was established from subcostal or apical four chamber cuts based on previously described criteria. ${ }^{14} 15$ The ventricles were identified according to the morphology of the atrioventricular valves, their attachments, and the overall appearances according to the methods described by Sutherland et al. ${ }^{16}$

The great arteries were distinguished by their course and branching pattern. ${ }^{317}$ Particular attention was paid to the sharp backwards course of the pulmonary trunk as seen in long axis cuts, the pulmonary bifurcation as seen subcostally or in short axis cuts from the precordium, and the long vertical course of the aorta, together with the origin of the coronary and head and neck arteries, as seen from subcostal, long axis, and suprasternal views.

Considerable use was made of subcostal scans. These began with short axis cuts of the apex of the heart and continued with rotation of the transducer counterclockwise, keeping the beam anterior so as to visualise the ventricular outlets until a two chamber long axis view of the right ventricle was obtained. Particular attention was paid to the nature of the roof of the interventricular communication. In the course of such a scan, it was frequently possible to obtain a view in which no such communication could be seen, and yet both great arteries originated from the right ventricle not the left. In other patients subcostal views could be obtained in which first one great artery could be seen to originate solely from the right ventricle and then the other could be seen to be doing the same. If both great arteries appeared to arise from the right ventricle, and yet one arterial valve appeared to override an interventricular communication, the apparently overriding valve was carefully scanned from back to front in an attempt to identify trabecular septum inserting into the ventriculoinfundibular fold on the left ventricular side of the supposedly overriding valve. If such a structure was identified double outlet right ventricle was diagnosed and the overriding shown to be spurious (Fig. 2). If this procedure still left the precise ventriculoarterial connexion in doubt other views were used. The most reproducible view is probably the parasternal long axis cut. Double outlet right ventricle was diagnosed if either of the great arteries could be seen originating anterior to the ventricular septum or in this view the central closure line of the cusps of the posterior great artery lay anterior to the crest of the ventricular septum. Where parasternal long axis cuts were difficult to interpret or had not been obtained short axis scans from great arteries to ventricles were studied, as described by Henry et al. ${ }^{2}$ Double outlet right ventricle was diagnosed if more than half of both great arterial roots were connected to the right ventricle. The presence of discontinuity between the atrioventricular and arterial valves was noted but not used as a criterion for the diagnosis of double outlet right ventricle. Once the diagnosis of double outlet right ventricle had been established careful attention was paid to the relation of atrioventricular valve tension apparatus to the pathway between the interventricular communication and the great arteries. This feature was best seen in subcostal cuts.

Cross sectional echocardiograms were recorded on either an ATL Mark V mechanical scanner with a 3 or $5 \mathrm{MHz}$ transducer, or a Toshiba SSH-10A phased array scanner. Recordings were made on 0.5 or 0.75 inch $(1.2$ or $1.9 \mathrm{~cm})$ video tape and were replayed using stop frame analysis for photography. The echocardiographic findings were then compared with angiocardiographic or operative findings. In order to provide detailed comparison with the anatomical findings cross sections were prepared of hearts in the collections of either hospital, particular note being taken of the hearts of patients who had previously undergone cross sectional echocardiographic examination. By judicious use of cyanoacrylate glue, it was possible to obtain several simulated echocardiographic cuts in the same heart.

\section{Results}

Of the 52 patients, $30(57.7 \%)$ were male and 22 (42.3\%) female. Their ages at the time of echocardiography ranged from 1 day to 17 years (median 21 months).

\section{GENERAL CARDIAC ARRANGEMENT}

The heart was in the left chest with the apex to the left in all patients. No patient had mirror image visceral arrangement (situs inversus). One patient had left isomerism and two right atrial isomerism, all with an ambiguous atrioventricular connexion and a right hand pattern of ventricular architecture. In the remainder, there was atrioventricular concordance. The side of the aortic arch was not echocardiographically identified in one patient, who was examined in 1980. It was to the left in 47 of the remainder (92.2\%). The pattern of ventricular architecture was as expected given atrioventricular concordance (right hand pattern), but in one patient the right ventricle was superior to the left.

\section{ACCURACY OF DIAGNOSIS OF DOUBLE OUTLET VENTRICLE}

Angiocardiograms were available for review in $\mathbf{4 0}$ of these patients and supported the diagnosis of double 

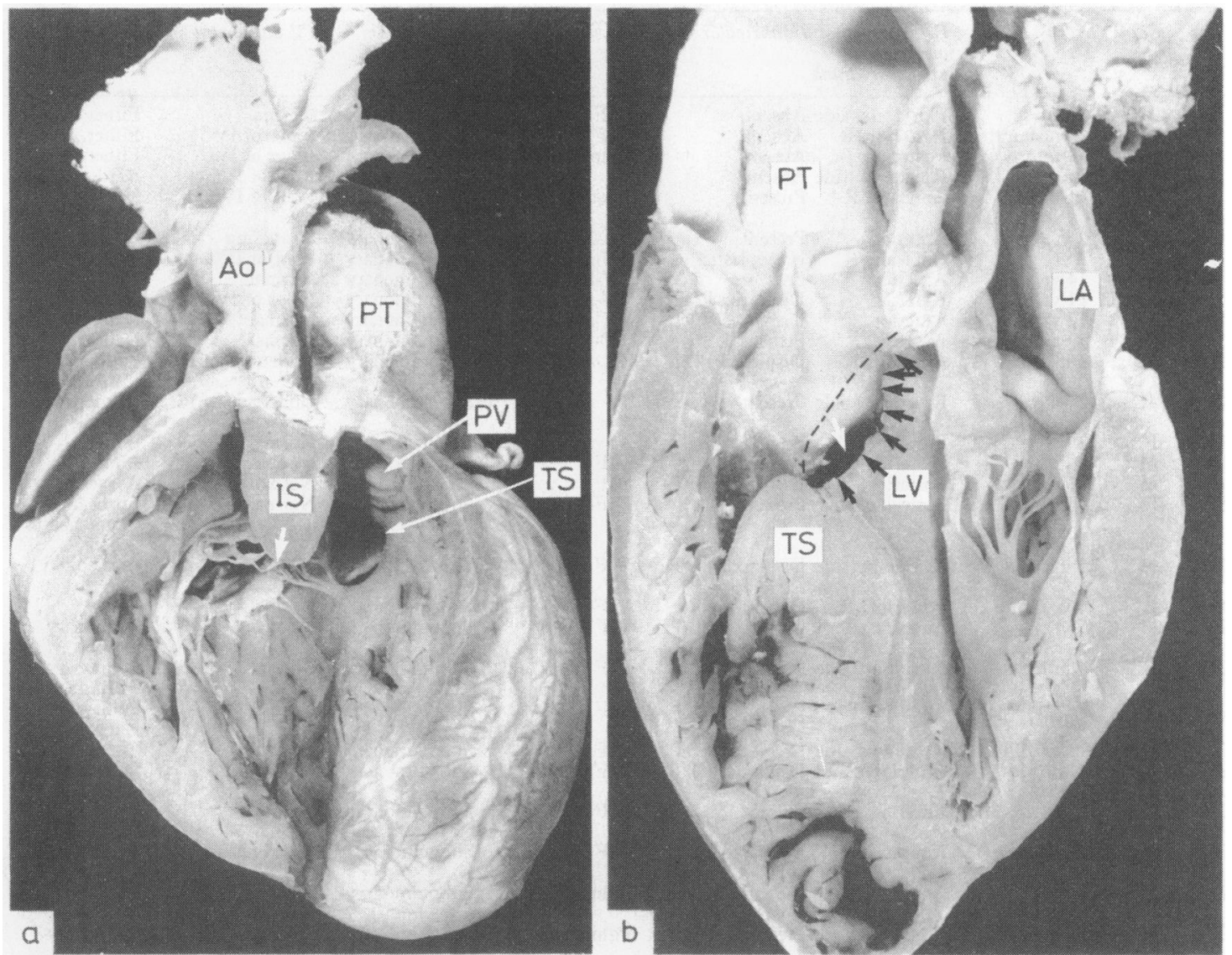

Fig. 2 Morphological appearance of heart with solitus-concordant-double outlet right ventricle with subpulmonary

interventricular communication. (a) In the frontal view part of the right ventricular free wall and outlet septum has been excised better to demonstrate the morphology. Note that the trabecular septum (TS) curves round posteriorly to the pulmonary valve (PV) to fuse with the ventriculoinfundibular fold, thus ensuring that the pulmonary trunk (PT) arises solely from the right ventricle. The infundibular (outlet) septum (IS) is therefore an entirely right ventricular structure. Note the insertion of the tricuspid valve into the underside of the outlet septum. (b) The same specimen has been cut to simulate a parasternal long axis view but is shown in its anatomical orientation.

Note that the pulmonary trunk (PT) and pulmonary valve, which in fact originate entirely above the right ventricle, appear to override the trabecular septum (TS). This is spurious overriding. The "defect" marked with a white arrow lies entirely within the right ventricle, whereas the true ventricular septal defect (interventricular communication), marked with black dashes and atrows, has been cut across in this section. $L A$, left atrium; $L V$, left ventricle, Ao, aorta.

outlet right ventricle in 38 (95\%). One patient with the defect overridden by the aortic valve had an angiocardiographic diagnosis of ventriculoarterial concordance and the other an angiocardiographic diagnosis of ventriculoarterial discordance. Here echocardiography showed the apparent overriding of the pulmonary valve to be spurious. No further evidence as to the correct diagnosis was available. In each of 19 cases the echocardiographic diagnosis was confirmed at open heart surgery and reconfirmed at necropsy in two. In one further case necropsy confirmed the diagnosis after death following a palliative shunt.

In six cases the surgical diagnosis at open heart operation was double outlet right ventricle, whereas the echocardiographic diagnosis was ventriculoarterial discordance in three and concordance in three. In each case cross sectional echocardiography correctly predicted that one arterial valve was overriding and also which valve this was. Thus the only difference was between surgical and echocardiographic assessment of the degree of overriding. In none of these patients was necropsy evidence available. In nine patients the clinical findings together with cross section echocardiography formed the only basis for the diagnosis.

The Table gives the most pertinent echocardiographic information in all the patients. 
Table Pertinent echocardiographic details

\begin{tabular}{|c|c|c|c|c|c|c|c|c|}
\hline $\begin{array}{l}\text { Case } \\
\text { No }\end{array}$ & Sex & Age & $\begin{array}{l}\text { Relation of } \\
\text { aorta to } \\
\text { pulmonary trunk }\end{array}$ & Infundibular septum & Roof of IVC & $\begin{array}{l}\text { Infundibulum } \\
\text { closest to IVC }\end{array}$ & $T V$ attachment & $\begin{array}{l}\text { Clear route } \\
(I V C \text { to } G A)\end{array}$ \\
\hline $\begin{array}{l}1 \\
2 \\
3 \\
4 \\
5\end{array}$ & $\begin{array}{l}M \\
F \\
F \\
M \\
M\end{array}$ & $\begin{array}{l}4 \mathrm{mth} \\
2 \mathrm{yr} 10 \mathrm{mth} \\
19 \mathrm{mth} \\
21 \mathrm{mth} \\
11 \mathrm{mth}\end{array}$ & $\begin{array}{l}\mathbf{R} \text {, side by side } \\
\text { Posterior, } R \\
\text { Posterior, } R \\
\mathbf{R} \text {, side by side } \\
\text { Anterior, } R\end{array}$ & $\begin{array}{l}\text { Absent } \\
\text { Absent } \\
\text { Absent } \\
\text { Absent } \\
\text { Present }\end{array}$ & $\begin{array}{l}\text { VIF } \\
\text { VIF } \\
\text { Pulmonary valve } \\
\text { TS } \\
\text { Inlet septum }\end{array}$ & $\begin{array}{l}\text { Subpulmonary } \\
\text { Subpulmonary } \\
\text { Subpulmonary } \\
\text { Subpulmonary } \\
\text { Subpulmonary }\end{array}$ & $\begin{array}{l}\text { Normal } \\
\text { Floor of IVC } \\
\text { Floor of IVC } \\
\text { Roof of IVC } \\
\text { Roof of IVC }\end{array}$ & $\begin{array}{l}\text { Either } \\
\text { Either } \\
\text { Either } \\
\text { Neither } \\
\text { Neither } \\
\text { (straddling MV) }\end{array}$ \\
\hline $\begin{array}{r}6 \\
7 \\
8 \\
9 \\
10 \\
11 \\
12\end{array}$ & $\begin{array}{l}\mathrm{F} \\
\mathrm{M} \\
\mathrm{M} \\
\mathrm{F} \\
\mathrm{F} \\
\mathrm{F} \\
\mathrm{M}\end{array}$ & $\begin{array}{l}2 \mathrm{yr} 6 \mathrm{mth} \\
7 \mathrm{yr} \\
14 \mathrm{yr} \\
11 \mathrm{yr} \\
17 \mathrm{yr} \\
5 \mathrm{yr} 3 \mathrm{mth} \\
3 \mathrm{mth}\end{array}$ & $\begin{array}{l}\text { Anterior } \\
\text { Anterior, } R \\
\text { Anterior } \\
\text { Anterior } \\
\text { Anterior } \\
\text { Anterior, } R \\
\text { Anterior, } \mathbf{R}\end{array}$ & $\begin{array}{l}\text { Present } \\
\text { Hypoplastic } \\
\text { Present } \\
\text { Displaced POT } \\
\text { Displaced POT } \\
\text { Present } \\
\text { Displaced POT }\end{array}$ & $\begin{array}{l}\text { TV-MV cont } \\
\text { TV-MV cont } \\
\text { TV-MV cont } \\
\text { TV-MV cont } \\
\text { TV-MV cont } \\
\text { TV-MV cont } \\
\text { TS }\end{array}$ & $\begin{array}{l}\text { Subpulmonary } \\
\text { Subpulmonary } \\
\text { Subpulmonary } \\
\text { Subpulmonary } \\
\text { Subpulmonary } \\
\text { Subpulmonary } \\
\text { Subpulmonary }\end{array}$ & $\begin{array}{l}\text { Straddling } \\
\text { Roof of IVC } \\
\text { Normal } \\
\text { Floor of IVC } \\
\text { Normal } \\
\text { Normal } \\
\text { Underside of IS }\end{array}$ & $\begin{array}{l}\text { Neither } \\
\text { Neither } \\
\text { Neither } \\
\text { Neither }^{\star} \\
\text { Neither }^{\star} \\
\text { Neither }^{\star} \\
\text { Pulmonary } \\
\text { trunk }\end{array}$ \\
\hline 13 & $\mathbf{M}$ & 2 wk & $\mathbf{R}$, side by side & Present & TS & Subpulmonary & Underside of IS & $\begin{array}{l}\text { Pulmonary } \\
\text { trunk }\end{array}$ \\
\hline $\begin{array}{l}14 \\
15 \\
16 \\
17\end{array}$ & $\begin{array}{l}\mathrm{F} \\
\mathrm{M} \\
\mathrm{M} \\
\mathrm{F}\end{array}$ & $\begin{array}{l}2 \mathrm{yr} \\
1 \mathrm{yr} \\
21 \mathrm{mth} \\
3 \mathrm{mth}\end{array}$ & $\begin{array}{l}\text { Posterior, L } \\
\text { Posterior, R } \\
\text { Posterior, R } \\
\text { Posterior, R }\end{array}$ & $\begin{array}{l}\text { Present } \\
\text { Present } \\
\text { Displaced POT } \\
\text { Present }\end{array}$ & $\begin{array}{l}\text { TS } \\
\text { VIF } \\
\text { VIF } \\
\text { VIF }\end{array}$ & $\begin{array}{l}\text { Equal } \\
\text { Subaortic } \\
\text { Subaortic } \\
\text { Subaortic }\end{array}$ & $\begin{array}{l}\text { Normal } \\
\text { Floor of IVC } \\
\text { Normal } \\
\text { Normal }\end{array}$ & $\begin{array}{l}\text { Either } \\
\text { Aorta } \\
\text { Aorta } \\
\text { Aorta (MV } \\
\text { attached to } \\
\text { floor) }\end{array}$ \\
\hline 18 & $M$ & $5 \mathrm{~d}$ & $\mathbf{R}$, side by side & Displaced POT & $\begin{array}{l}\text { VIF } \\
\text { TV-MV cont }\end{array}$ & Subaortic & Floor of IVC & Aorta \\
\hline $\begin{array}{l}19 \\
20\end{array}$ & $\begin{array}{l}\mathrm{F} \\
\mathrm{M}\end{array}$ & $\begin{array}{l}4 \mathrm{yr} 6 \mathrm{mth} \\
5 \mathrm{yr}\end{array}$ & $\begin{array}{l}\text { Posterior, } \mathbf{R} \\
\text { Anterior, } \mathbf{R}\end{array}$ & $\begin{array}{l}\text { Present } \\
\text { Displaced POT }\end{array}$ & $\begin{array}{l}\text { VIF } \\
\text { VIF }\end{array}$ & $\begin{array}{l}\text { Subaortic } \\
\text { Subpulmonary }\end{array}$ & $\begin{array}{l}\text { Normal } \\
\text { Floor of IVC }\end{array}$ & $\begin{array}{l}\text { Aorta } \\
\text { Pulmonary } \\
\text { trunk }\end{array}$ \\
\hline 21 & F & $4 \mathrm{mth}$ & $\mathbf{R}$, side by side & Present & VIF & Subpulmonary & Underside of IS & $\begin{array}{l}\text { Pulmonary } \\
\text { trunk }\end{array}$ \\
\hline 22 & $\mathbf{M}$ & $7 d$ & Anterior, R & Present & VIF & Subpulmonary & Normal & $\begin{array}{l}\text { Pulmonary } \\
\text { trunk }\end{array}$ \\
\hline $\begin{array}{l}23 \\
24\end{array}$ & $\begin{array}{l}\mathrm{F} \\
\mathrm{F}\end{array}$ & $\begin{array}{l}13 \mathrm{yr} 10 \mathrm{mth} \\
1 \mathrm{wk}\end{array}$ & $\begin{array}{l}R \text {, side by side } \\
\text { Anterior, } R\end{array}$ & $\begin{array}{l}\text { Displaced POT } \\
\text { Displaced POT }\end{array}$ & $\begin{array}{l}\text { VIF } \\
\text { VIF }\end{array}$ & $\begin{array}{l}\text { Subpulmonary } \\
\text { Subpulmonary }\end{array}$ & $\begin{array}{l}\text { Normal } \\
\text { Normal }\end{array}$ & $\begin{array}{l}\text { Either } \\
\text { Pulmonary } \\
\text { trunk }\end{array}$ \\
\hline 25 & $\mathbf{F}$ & $8 \mathrm{yr}$ & Anterior, $\mathbf{R}$ & Present & VIF & Subpulmonary & Normal & $\begin{array}{l}\text { Pulmonary } \\
\text { trunk }\end{array}$ \\
\hline 26 & $\mathbf{M}$ & $2 \mathrm{yr} 7 \mathrm{mth}$ & Anterior, $\mathbf{R}$ & Displaced POT & VIF & Subpulmonary & Underside of IS & $\begin{array}{l}\text { Neither } \\
\text { (straddling MV) }\end{array}$ \\
\hline 27 & $\mathbf{M}$ & $7 d$ & Anterior, L & Present & Pulmonary valve & Subpulmonary & $\begin{array}{l}\text { Floor of IVC } \\
\text { and IS }\end{array}$ & $\begin{array}{l}\text { Pulmonary } \\
\text { trunk }\end{array}$ \\
\hline 28 & $\mathbf{M}$ & $15 \mathrm{mth}$ & $R$, side by side & Present & Pulmonary valve & Subpulmonary & $\begin{array}{l}\text { Floor of IVC } \\
\text { and IS }\end{array}$ & $\begin{array}{l}\text { Pulmonary } \\
\text { trunk }\end{array}$ \\
\hline 29 & $\mathrm{~F}$ & $3 \mathrm{yr}$ & Anterior, L & Displaced POT & Pulmonary valve & Subpulmonary & Floor of IVC & $\begin{array}{l}\text { Pulmonary } \\
\text { trunk }\end{array}$ \\
\hline 30 & $\mathbf{M}$ & $10 \mathrm{yr}$ & Anterior & $\begin{array}{l}\text { Hypoplastic and } \\
\text { displaced POT }\end{array}$ & Pulmonary valve & Subpulmonary & Floor of IVC & $\begin{array}{l}\text { Pulmonary } \\
\text { trunk }\end{array}$ \\
\hline 31 & $M$ & 4 wk & $\mathbf{R}$, side by side & Present & Pulmonary valve & Subpulmonary & Normal & $\begin{array}{l}\text { Pulmonary } \\
\text { trunk }\end{array}$ \\
\hline 32 & $\mathrm{~F}$ & $1 \mathrm{~d}$ & Anterior, $\mathbf{R}$ & Present & Pulmonary valve & Subpulmonary & Normal & $\begin{array}{l}\text { Pulmonary } \\
\text { trunk }\end{array}$ \\
\hline 33 & $M$ & $16 \mathrm{mth}$ & Anterior & Present & Pulmonary valve & Subpulmonary & Normal & $\begin{array}{l}\text { Pulmonary } \\
\text { trunk }\end{array}$ \\
\hline 34 & $M$ & $4 \mathrm{mth}$ & Posterior, $\mathbf{R}$ & Present & Pulmonary valve & Subpulmonary & Normal & Pulmonary \\
\hline 35 & $\mathbf{F}$ & $6 \mathrm{wk}$ & $R$, side by side & Present & Pulmonary valve & Subpulmonary & Normal & $\begin{array}{l}\text { Pulmonary } \\
\text { trunk }\end{array}$ \\
\hline 36 & M & $6 \mathrm{wk}$ & Anterior & Present & Pulmonary valve & Subpulmonary & Normal & $\begin{array}{l}\text { Neither } \\
\text { (straddling MV) }\end{array}$ \\
\hline $\begin{array}{l}37 \\
38 \\
39 \\
40 \\
41 \\
42 \\
43 \\
44 \\
45 \\
46 \\
47 \\
48 \\
49 \\
50 \\
51 \\
52\end{array}$ & $\begin{array}{l}M \\
M \\
F \\
F \\
F \\
M \\
M \\
M \\
F \\
M \\
F \\
M \\
M \\
M \\
M \\
F\end{array}$ & $\begin{array}{l}13 \mathrm{mth} \\
10 \mathrm{yr} \\
10 \mathrm{yr} \\
10 \mathrm{yr} \\
6 \mathrm{yr} \\
5 \mathrm{~d} \\
1 \mathrm{mth} \\
19 \mathrm{~d} \\
10 \mathrm{~d} \\
6 \mathrm{yr} \\
3 \mathrm{yr} \\
4 \mathrm{mth} \\
5 \mathrm{yr} \\
4 \mathrm{yr} \\
8 \mathrm{yr} \\
5 \mathrm{wk}\end{array}$ & $\begin{array}{l}\text { Posterior, } \mathbf{R} \\
\text { Posterior, } \mathbf{R} \\
\mathbf{R} \text {, side by side } \\
\mathbf{R} \text {, side by side } \\
\text { Posterior, } \mathbf{R} \\
\text { Posterior, } \mathbf{R} \\
\mathbf{R} \text {, side by side } \\
\text { Posterior, } \mathbf{R} \\
\text { Posterior, } \mathbf{R} \\
\mathbf{R} \text {, side by side } \\
\mathbf{R} \text {, side by side } \\
\mathbf{R} \text {, side by side } \\
\mathbf{R} \text {, side by side } \\
\text { Posterior, } \mathbf{R} \\
\mathbf{R} \text {, side by side } \\
\text { Posterior, } \mathbf{R}\end{array}$ & $\begin{array}{l}\text { Displaced POT } \\
\text { Present } \\
\text { Present } \\
\text { Hypoplastic } \\
\text { Present } \\
\text { Displaced POT } \\
\text { e Present } \\
\text { Displaced POT } \\
\text { Displaced POT } \\
\text { e Present } \\
\text { e Present } \\
\text { e Present } \\
\text { e Present } \\
\text { Displaced POT } \\
\text { e Present } \\
\text { Displaced POT }\end{array}$ & $\begin{array}{l}\text { Aortic valve } \\
\text { Aortic valve } \\
\text { Aortic valve } \\
\text { Aortic valve } \\
\text { Aortic valve } \\
\text { Aortic valve } \\
\text { Aortic valve } \\
\text { Aortic valve } \\
\text { Aortic valve } \\
\text { Aortic valve } \\
\text { Aortic valve } \\
\text { Aortic valve } \\
\text { Aortic valve } \\
\text { Aortic valve } \\
\text { Aortic valve } \\
\text { Aortic valve }\end{array}$ & $\begin{array}{l}\text { Subaortic } \\
\text { Subaortic } \\
\text { Subaortic } \\
\text { Subaortic } \\
\text { Subaortic } \\
\text { Subaortic } \\
\text { Subaortic } \\
\text { Subaortic } \\
\text { Subaortic } \\
\text { Subaortic } \\
\text { Subaortic } \\
\text { Subaortic } \\
\text { Subaortic } \\
\text { Subaortic } \\
\text { Subaortic } \\
\text { Subaortic }\end{array}$ & $\begin{array}{l}\text { Floor of IVC } \\
\text { Floor of IVC } \\
\text { Floor of IVC } \\
\text { Floor of IVC } \\
\text { Floor of IVC } \\
\text { Normal } \\
\text { Normal } \\
\text { Normal } \\
\text { Normal } \\
\text { Normal } \\
\text { Normal } \\
\text { Normal } \\
\text { Normal } \\
\text { Normal } \\
\text { Normal } \\
\text { Normal }\end{array}$ & $\begin{array}{l}\text { Aorta } \\
\text { Aorta } \\
\text { Aorta } \\
\text { Aorta } \\
\text { Aorta } \\
\text { Aorta } \\
\text { Aorta } \\
\text { Aorta } \\
\text { Aorta } \\
\text { Aorta } \\
\text { Aorta } \\
\text { Aorta } \\
\text { Aorta } \\
\text { Aorta } \\
\text { Aorta } \\
\text { Aorta }\end{array}$ \\
\hline
\end{tabular}

॥Inferred rather than directly demonstrated.

Displaced POT, displaced into pulmonary outflow tract; GA, great artery; IS, infundibular septum; IVC, interventricular communication; MV, mitral valve; POT, pulmonary outflow tract; TS, trabecular septum; TV, tricuspid valve; TV-MV cont, area of tricuspid/mitral continuity; VIF, ventriculoinfundibular fold. 


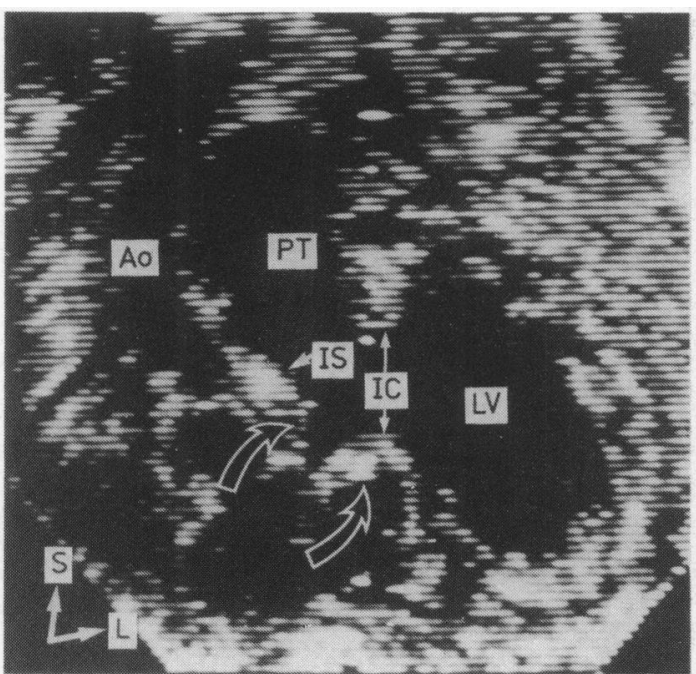

Fig. 3 Echocardiographic subcostal oblique four chamber view in a patient with solitus-concordant-double outlet right ventricle with trabecular septal defect (IC). The tricuspid valve (open arrows) is inserted into both the floor of the defect and the infundibular (outlet) septum (IS). Ao, aorta; $L V$, left ventricle; $P T$, pulmonary trunk; $S$, superior; $L$, left.

ROLE OF THE OUTLET SEPTUM IN DETERMINING THE RELATION BETWEEN THE

INTERVENTRICULAR COMMUNICATION AND THE OUTFLOW TRACTS

The outlet septum was present in 48 of the 52 patients (cases 5-52). It was the course of this structure which largely determined which outflow tract was more closely related to the interventricular communication. This was best seen in oblique subcostal cuts somewhere in orientation between short axis and four chamber planes (Figs. 3 and 4) which lie more or less in the coronal plane of the body. Given that the pulmonary outflow tract was to the left of the aortic outflow (as it was in all but five patients), if the outlet septum lay straight and parallel to the apical trabecular septum the defect automatically lay closer to the pulmonary outflow tract (Fig. 3). If, on the other hand, the outlet septum, descending from the junction between the arterial valves, curved leftward to fuse with the ventriculoinfundibular fold it blocked the direct route from ventricular septal defect to pulmonary outflow tract, bringing the defect into relation with the subaortic outflow tract (Fig. 4c). This arrangement caused the pulmonary outflow tract to appear as a circle or ellipse cut more or less in its short axis. The only exception was in a single patient with a mildly curved outlet septum whose defect was subpulmonary. The true anatomical position was easily established by tilting the transducer anteriorly from the rather posterior pulmonary valve, thereby bringing the pulmonary outflow tract into sight in its usual position. In most patients with subaortic defects the entrance to the subpulmonary infundibulum could be demonstrated subcostally by rotating the transducer into a right ventricular long axis cut (Fig. 5). In this group as a whole, the outlet septum was displaced into the pulmonary outflow tract in 18 , thereby producing subpulmonary obstruction $(37.5 \%)$.

In four patients (cases 1-4) there was no outlet septum with the result that in multiple views, but most obviously in the subcostal right ventricular long axis cut (Fig. 6), both arterial valves were in continuity. In these patients the relation of the outflow tracts to the interventricular communication was determined by the relation of the great arteries one to the other. Since in each case the aorta was to the right the pulmonary outflow was invariably closer to the interventricular communication (Fig. 6b, c).

\section{NATURE OF THE PATHWAY FROM THE} INTERVENTRICULAR COMMUNICATION TO THE VENTRICULAR OUTLETS

Three principal factors determined the nature of this pathway-namely the proximity of the outflow tracts to the interventricular communication, which has already been discussed, the nature of the roof of the interventricular communication, and the insertion of atrioventricular valve tension apparatus. As will be seen, there is almost no predictable relation between these different factors so the insertion of atrioventricular valves has been described under each of three different categories of "roof formation." Were this scheme to be applied rigidly, however, it would obscure some important observations in patients with absence of the outlet septum, which are therefore considered first. The 48 patients possessing an outlet septum are then categorised according to the roof of the interventricular communication.

\section{Absence of outlet septum}

In four patients (cases 1-4) the interventricular communications could well be regarded as doubly committed. ${ }^{9}$ In three (cases 1-3) this was indeed the case, although the pulmonary valve was closest to the defect. In two of these patients, the roof of the interventricular communication, viewed from the subcostal position, was formed by a smoothly curved muscular structure, the ventriculoinfundibular fold (Fig. 6c), whereas in the third the pulmonary valve overrode the defect. The tricuspid valve in two of these patients inserted into the floor of the interventricular communication (one had a second central trabecular defect) and in the third was normally inserted. In none of the three did tension apparatus interpose between defect and great arteries. The 

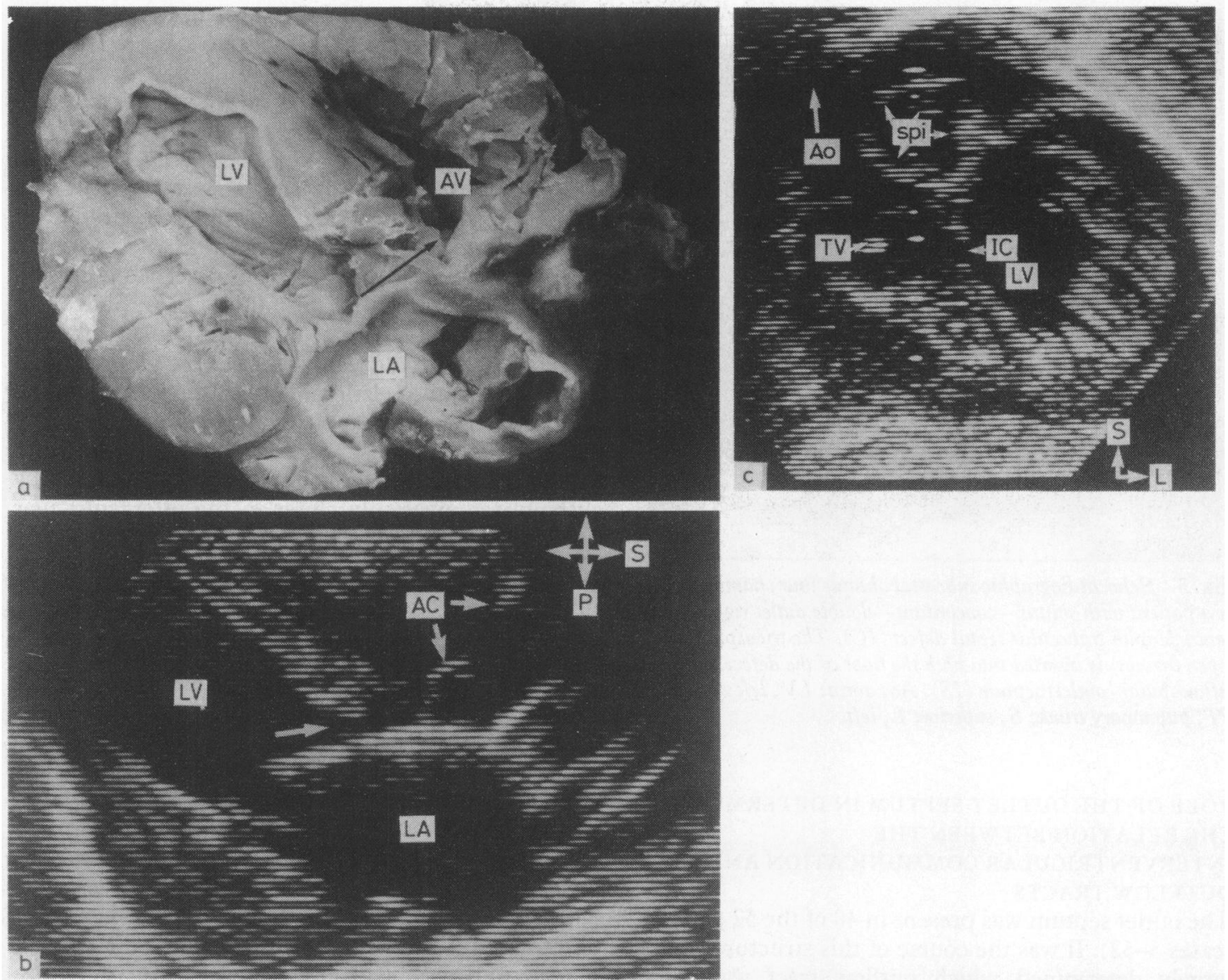

Fig. 4 (a) Morphological appearance in simulated parasternal long axis cut in specimen with solitus-concordant-double outlet right ventricle with obstructive subaortic interventricular communication. Note the marked endocardial thickening in both the left atrium (LA) and left ventricle (LV). The cut has passed, almost but not quite, through the interventricular communication (interrupted black arrow). The aortic valve ( $A V)$ is seen arising above the morphological right ventricle. (b) Echocardiographic parasternal long axis view in the same patient in life. Note the similarities in $(a)$ and $(b)$. Solitary white arrow points to the interventricular communication. AC, aortic cusps; $P$, posterior; $S$, superior. Other abbreviations as in $(a)$. (c) Echocardiographic subcostal oblique four chamber view in the same patient. Note the way in which the outlet septum curves in its downward path in such a way as to wall off the subpulmonary infundibulum (spi), thus causing the defect to lie in subaortic position. In this case, the superior margin of the interventricular communication is formed by a frill offibrous tissue which encircles the defect (see (a) and Fig. $6 c)$. Note also the severe left ventricular hypertrophy. Ao, aorta; $L$, left; TV, tricuspid valve. Other abbreviations as in (a).

fourth case (case 4) without an outlet septum was more complex (Fig. 6a, b). The roof of the defect was formed by a small rim of trabecular septum fusing with the ventriculoinfundibular fold. Part of the tensor apparatus of the tricuspid valve inserted into this fusion point, thus blocking any direct route for an intracardiac conduit from the interventricular defect to either great artery. The aortic valve lay directly to the right of the pulmonary valve. Thus this defect, doubly committed in the pathological sense, was non-committed from the surgical point of view. A complete tubular intracardiac conduit had to be inserted to avoid the tricuspid tension apparatus. These details were confirmed at open heart surgery in three of the four patients.

Communications not roofed by ventriculoinfundibular fold or overriding arterial valve

Such defects are all, strictly speaking, remote from the ventricular outlets. They are thereby uncommitted and present considerable problems with surgical repair. The degree of surgical difficulty varied widely between the 10 patients (cases 5-14). Beginning with the technically most taxing, two patients had overrid- 

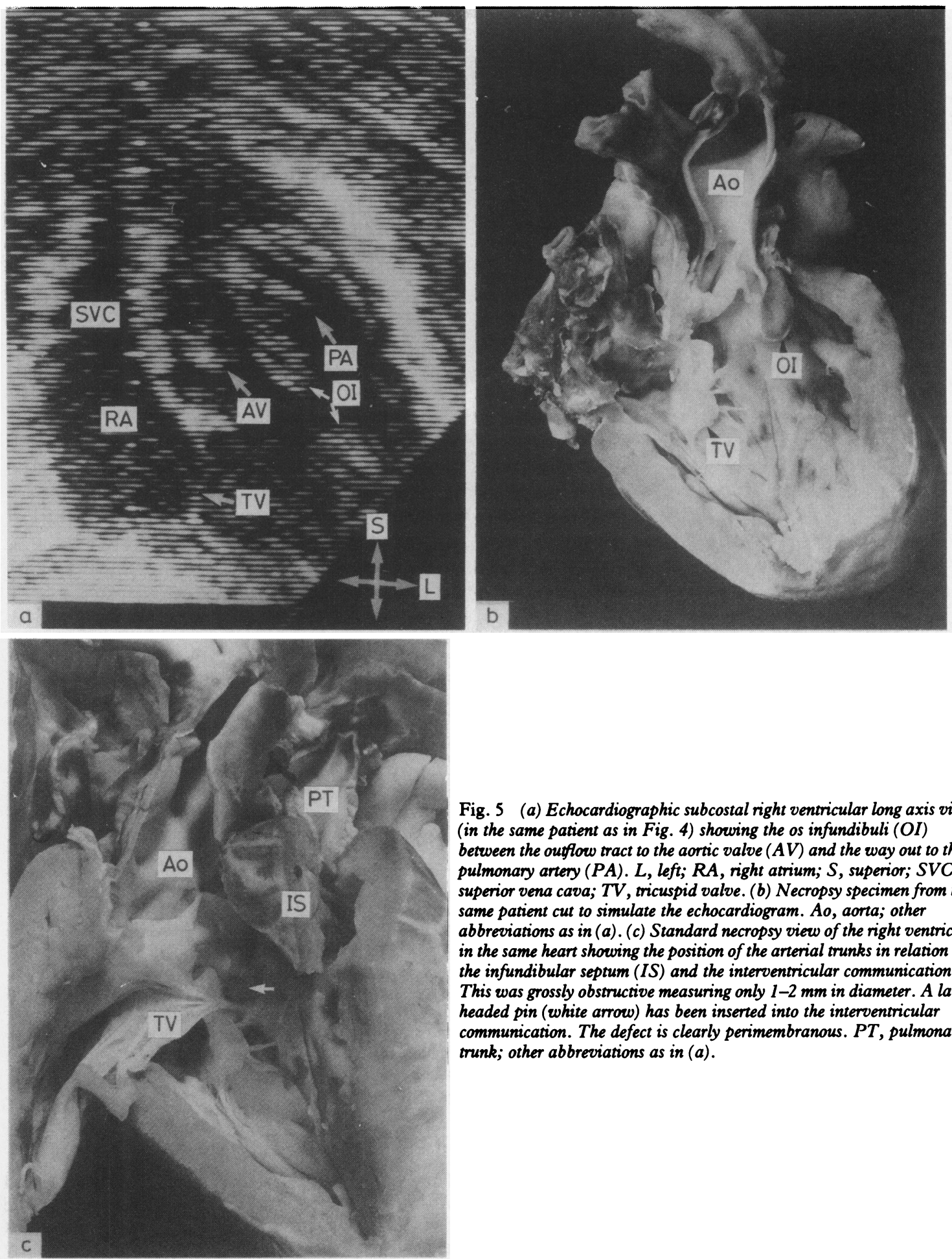

Fig. 5 (a) Echocardiographic subcostal right ventricular long axis view (in the same patient as in Fig. 4) showing the os infundibuli (OI) between the outflow tract to the aortic valve $(A V)$ and the way out to the pulmonary artery (PA). $L$, lefi; $R A$, right atrium; $S$, superior; SVC, superior vena cava; TV, tricuspid valve. (b) Necropsy specimen from the same patient cut to simulate the echocardiogram. Ao, aorta; other abbreviations as in (a). (c) Standard necropsy view of the right ventricle in the same heart showing the position of the arterial trunks in relation to the infundibular septum (IS) and the interventricular communication. This was grossly obstructive measuring only 1-2 $\mathrm{mm}$ in diameter. A large headed pin (white arrow) has been inserted into the interventricular communication. The defect is clearly perimembranous. PT, pulmonary trunk; other abbreviations as in (a). 

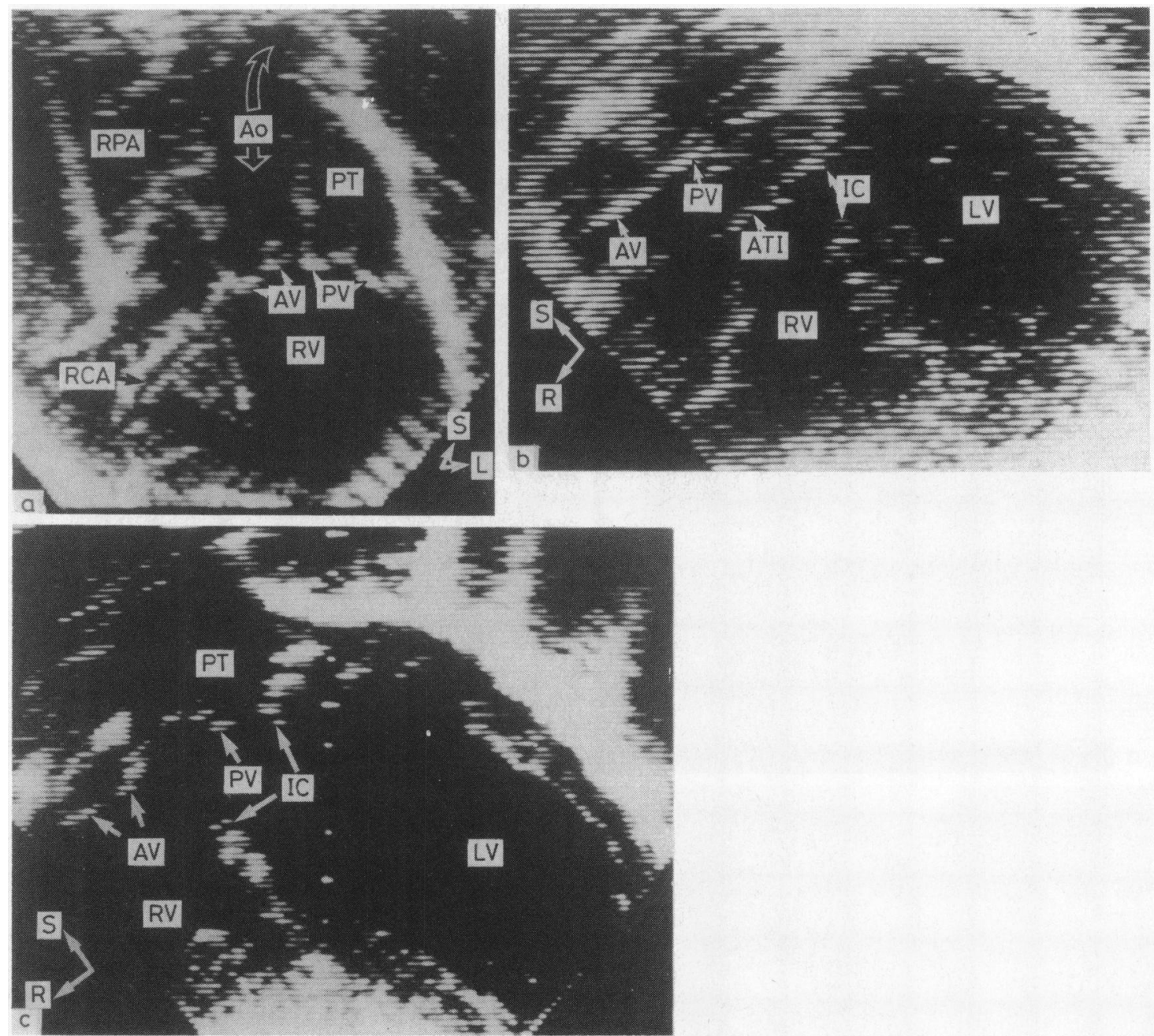

Fig. 6 (a) Echocardiographic subcostal right ventricular long axis view in a patient with double outlet right ventricle with absence of the outlet septum. Note that the aortic valve $(A V)$ and the pulmonary valve $(P V)$ are in continuity and not separated by outlet septum. The right coronary artery $(R C A)$ is well seen in the right atrioventricular groove. Ao, aorta; $L$, left; $P T$, pulmonary trunk; RPA, right pulmonary artery; $R V$, right ventricle; $S$, superior. (b) Echocardiographic oblique four chamber plane in the same patient. The interventricular communication (IC) lies high in the trabecular septum. The semilunar valves are seen in continuity as before. Between the interventricular communication and both semilunar valves is an anomalous tricuspid valve insertion $(A T I)$ preventing free access to either semilunar valve from the ventricular septal defect. At open heart surgery it was impossible to connect either great artery to the left ventricle $(L V)$ using a standard interventricular conduit. Instead a complete tubular conduit was used to connect the ventricular septal defect to the aortic valve. $R$, right; $R V$, right ventricle; other abbreviations as in $(a)$. (c) Echocardiographic view in a similar cut to that in $(b)$ in a different patient who had double outlet right ventricle without an outlet septum. Note the continuity between the aortic valve $(A V)$ and the pulmonary valve $(P V)$. The interventricular communication (IC), in contrast to that in Fig. $3 b$, lies immediately below the pulmonary valve, and there is no tensor apparatus interposing between it and either atrioventricular valve. Other abbreviations as in $(a)$ and $(b)$.

ing and straddling atrioventricular valves. In one patient (case 5) the mitral valve, itself affected by an isolated cleft, ${ }^{18}$ straddled a malalignment defect between the inlet and apical trabecular septal structures.
Worse still, part of the tricuspid valve was inserted into the roof of this defect. In another (case 6) the tricuspid valve straddled a perimembranous inlet defect. ${ }^{15}$ In neither case was surgical or necropsy 

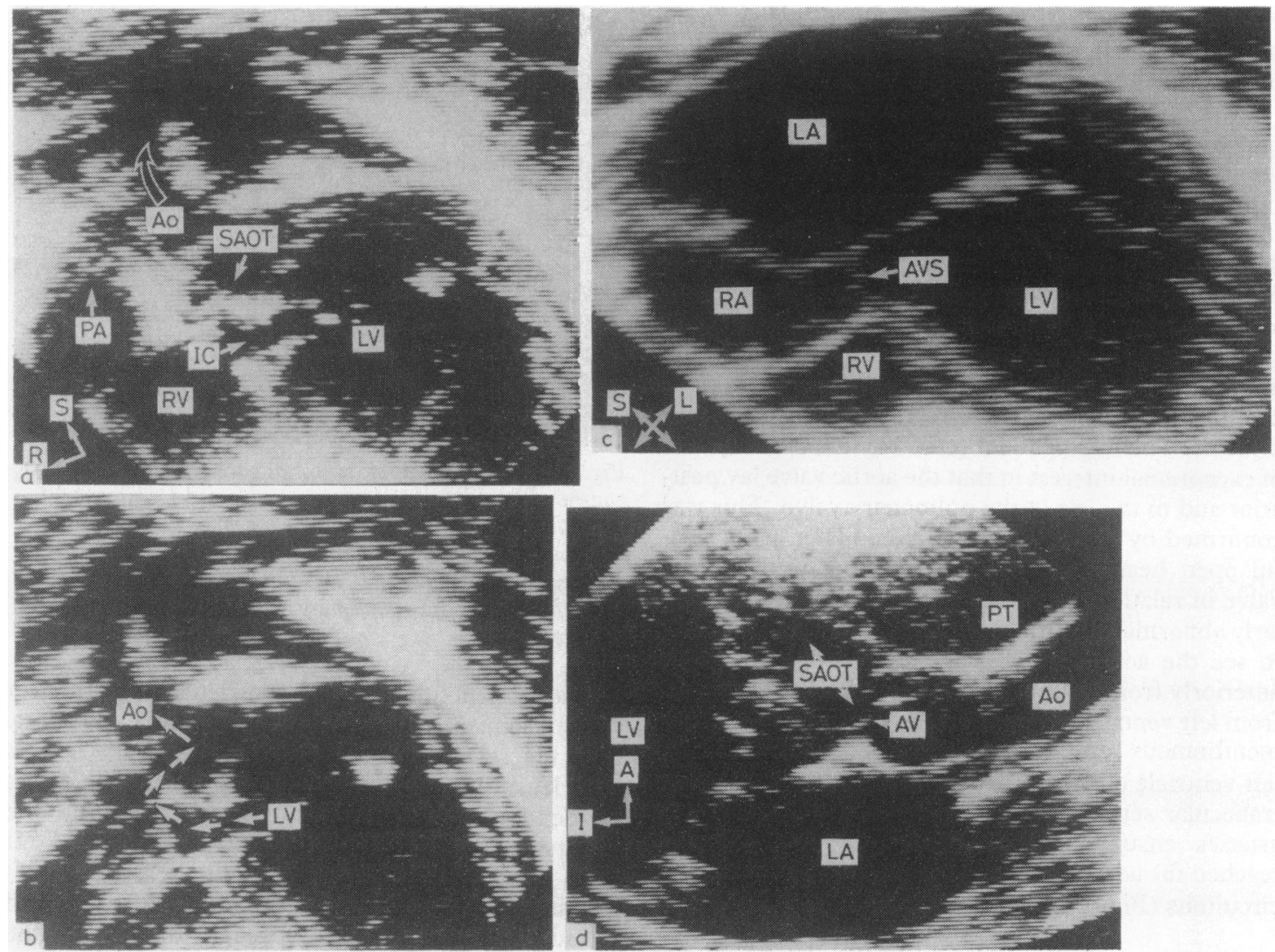

Fig. 7 Echocardiographic views in a patient with solitus-concordant-double outlet right ventricle with obstructive interventricular communication and mild subaortic obstruction. The aortic root lay posterior and to the left of the pulmonary root, as confirmed at open heart surgery and by angiocardiography. (a) A subcostal paracoronal view shows a long tunnel-like interventricular communication (IC) forming the only exit from the left ventricle ( $L V)$. At first sight, however, the aorta (Ao) might be thought to be originating from the left ventricle, so normal is its relation to it. PA, pulmonary artery; $R$, right; $R V$, right ventricle; $S$, superior; $S A O T$, subaortic outflow tract. (b) With slight angulation of the transducer, the entire and extremely circuitous route from left ventricle to aorta is shown; abbreviations as in (a). (c) A subcostal four chamber view showed that as the transducer was tilted forward from the atrioventricular valves to show the left ventricular oufflow tract, this appeared blocked by the atrioventricular septum (AVS). L, left; LA, left atrium; $R A$, right atrium; $S$, superior; other abbreviations as before. (d) Parastemal long axis view in this patient shows the grossly abnormal orientation of the subaortic oufflow tract (SAOT) leading up to the aortic valve (AV). The pulmonary trunk $(P T)$ lies anterior to the aorta (Ao). A, anterior; I, inferior; other abbreviations as before.

confirmation available.

In one patient (case 7) the defect was roofed by the mitral and tricuspid valves in continuity (perimembranous defect), with the mitral valve overriding the crest of the ventricular septum by about $20 \%$ but not straddling it. The pulmonary valve was closer to the defect than the aortic valve, but tension apparatus from both atrioventricular valves interposed between the interventricular communication and both great arteries. The surgeons were warned that repair would be difficult. These details were confirmed at operation. Repair was successfully achieved by closure of the ventricular septal defect in such a way as to leave the aorta coming from the right ventricle. The proximal pulmonary trunk was closed off, a valved left ventricular to pulmonary artery conduit inserted, and Senning's procedure carried out.

In four patients the interventricular communication was confined to the inlet septum, being roofed by the two atrioventricular valves in continuity (perimembranous inlet defects). In three of these (cases 8-10) the aorta lay directly anterior to the pulmonary artery, whereas in the fourth (case 11) there were superoinferior ventricles, confirmed at open heart surgery. Repair would have been, or was, even further complicated in this group by an additional trabecular muscu- 
lar defect in two patients, one of whom had an overriding but not straddling tricuspid valve confirmed at surgery and necropsy.

In three patients the interventricular communication lay entirely within the upper anterior trabecular septum (muscular defect) and therefore facilitated surgical repair. In two of these (cases 12 and 13), one confirmed at operation (Fig. 3), the defect lay close to the pulmonary outflow tract and there was no factor preventing connexion of the pulmonary trunk to the left ventricle by a standard intraventricular conduit. In both cases insertion of the tricuspid valve into the underside of the outlet septum would have made connexion of the left ventricle to the aorta particularly difficult. The third patient (case 14) in this group was of exceptional interest in that the aortic valve lay posterior and to the left of the pulmonary valve. This was confirmed by angiocardiography and later at successful open heart surgery. The position of the aortic valve in relation to the left ventricle was not particularly abnormal but, in the site where one would expect to see the aortic valve as the transducer was tilted anteriorly from a subcostal four chamber cut, the exit from left ventricle was blocked by the atrioventricular membranous septum (Fig. 7c). Blood could leave the left ventricle only by an obstructive defect high in the trabecular septum. The curious relation of the great arteries ensured that the route by which blood reached the aorta from the left ventricle was extremely circuitous (Fig. 7b).

Communications roofed by the ventriculoinfundibular fold

There were 12 such patients (cases 15-26), in seven of whom the interventricular communication was adjacent to the subpulmonary infundibulum (subpulmonary) and in five of whom it opened into the subaortic infundibulum (subaortic).

In the five patients with subaortic communications these were obstructive in two (cases 15 and 16), the lower margin in particular being obstructed by fibrous tissue tags. The tricuspid valve was attached to the lower margin in one of these two (case 15) but normal in the remaining four. Nevertheless, the mitral valve inserted into the floor of the defect in one patient (case 17) (Fig. 8), which might have complicated surgical repair. In another patient the interventricular communication, although extending superiorly into subaortic position, also extended so far posteriorly between the mitral and tricuspid valves in continuity (inlet perimembranous defect, case 18) that it is difficult to conceive how a baffle could have been inserted without compromising tricuspid tensor apparatus. Surgical or necropsy confirmation of these diagnoses was available in only the two patients with obstructive defects, in both of whom the surgical

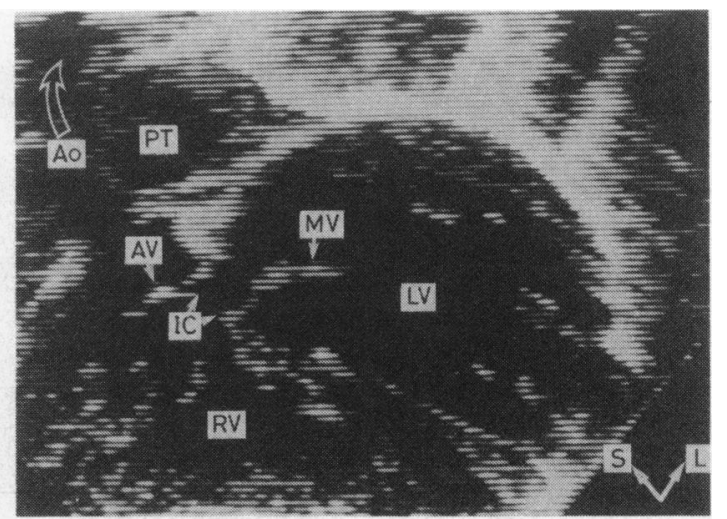

Fig. 8 Echocardiographic subcostal paracoronal view of patient with solitus-concordant-double outlet right ventricle with subaortic interventricular communication (IC). Note the abnormal insertion of the mitral valve (MV) into the floor of the ventricular septal defect. Ao, aorta; $A V$, aortic valve; $L$, left; $L V$, left ventricle; $P T$, pulmonary trunk; $R V$, right ventricle; $S$, superior.

diagnosis of non-committed ventricular septal defect was subsequently shown at necropsy to be incorrect.

In the seven patients with subpulmonary defects the tricuspid valve inserted into the floor of the defect in one (case 20) (confirmed at operation) and into the underside of the outlet septum in another (case 21). It was normally inserted in four (cases 22-25) (confirmed at operation in one); one of these four had an additional muscular trabecular defect. In the seventh patient (case 26) the basal defect was straddled by the mitral valve and there was a further muscular trabecular defect. Part of the tricuspid tension apparatus inserted into the underside of the outlet septum.

\section{Communications with overriding arterial valves}

There were 26 such patients (cases 27-52); in 10 (cases 27-36) the communication was subpulmonary. In two of these tricuspid apparatus inserted into both the underside of the outlet septum and the crest of the ventricular septum (cases 27 and 28). In both patients these details were confirmed at a successful repair of the anomaly by closure of the defect such as to direct left ventricular blood to the pulmonary trunk. In one of these (case 27) the great arteries were switched, whereas in the other (case 28) a Senning operation was performed. In two patients (cases 29 and 30) the tricuspid valve inserted into the floor of the interventricular communication, whereas in the remainder (cases 31-35) the tricuspid valve insertions were normal. This was confirmed at open heart surgery in two. In one patient (case 36), although the septal crest was directly beneath an overriding pulmonary valve, it was also straddled (but not overridden) by the 
mitral valve. This patient survived banding of the pulmonary trunk but has not had complete repair attempted.

In the 16 patients with subaortic defects (cases 3752) the tricuspid valve was attached to the lower margin of the interventricular communication in four (cases 37-41) but was normal in all the rest. These details were confirmed at necropsy in one and at open heart surgery in a further seven.

\section{Discussion}

Double outlet right ventricle is a difficult anomaly to treat surgically. Even in the best of circumstances, where the aorta is to the right and the defect is subaortic, the combined results of five large surgical series ${ }^{19-23}$ gives a hospital mortality of 28 out of 116 (24.1\%). For subpulmonary and non-committed defects the mortality is even higher. ${ }^{21} 22$ Two more recent series ${ }^{24} 25$ indicate a somewhat lower risk than indicated above, but the way in which the results were presented makes comparison with these earlier reports difficult.

Our own experience before the advent of cross sectional echocardiography mirrors that reported by others, ${ }^{22}$ in that definitive repair is sometimes undertaken only to be abandoned in the light of the intraoperative findings. If this is so one of the most likely causes of operative mortality in the past has been defective patient selection. If surgical repair requires the use of double conduits, ${ }^{26}$ insertion of a tubular interventricular conduit, ${ }^{27} \mathbf{2 8}$ or sacrifice of one atrioventricular valve it certainly should not be undertaken in infancy. If, on the other hand, only a standard intraventricular baffle with or without relief of pulmonary stenosis is required, there is no particular reason why primary repair should not be undertaken in infancy.

Angiocardiography and cardiac catheterisation have largely failed to provide the preoperative information required. They cannot demonstrate the location of valve tension apparatus and are not particularly good at defining the relation of the great arteries to the interventricular communication, even when the final diagnosis is known when the data are reviewed. 2930 However good the resolution of the image the inherent problem in interpreting a projection is that structures overlap. Thus if the trabecular septum is profiled any defect in the region of the outflow tracts will appear to be closer to the posterior and more leftward of the two great arteries regardless of whether the defect is subaortic or subpulmonary.

Because it shows cross sectional anatomy and not projections echocardiography is not subject to these inherent problems of overlapping structures. Our studies show that it is highly accurate at showing the relation of the interventricular communication to the outflow tracts. Which cross sectional plane shows this best probably depends on the age of the patient. Sanders and colleagues correctly diagnosed 11 out of 12 infants with double outlet right ventricle using subcostal echocardiography alone. ${ }^{7}$ Defects were categorised as subaortic, subpulmonary, or uncommitted, but the standard against which validity was determined was angiocardiography. By contrast, Hagler and colleagues reported 28 patients in whom the diagnosis was confirmed at surgery, and only eight in whom angiocardiography was the only basis for comparison. 5 The relation of the defect to the great arteries was correctly predicted in each case. Although these workers used subcostal examination their illustrations were all from precordial views, presumably because their patients were much older (mean age 10.1 years). In our experience, provided adequate penetration is achieved, subcostal examination provides the most information since it is invariably possible to show the interventricular communication and at least one great artery (and usually both) in the same cut, thereby illustrating clearly the relation between them. Furthermore, as we had suspected, ${ }^{31}$ subcostal cuts show the key difference in insertion of the outlet septum between subpulmonary and subaortic defects and the attachment (if any) of the tricuspid valve to the underside of the outlet septum. The disadvantage of the subcostal approach is, firstly, that it is not always possible in older patients. The second problem is that if there is real (as opposed to spurious) overriding of the ventricular septal crest by a great artery, with slight shifts in transducer angulation, that great artery can be made to appear to originate predominantly from either ventricle at will. Thus subcostal examination is unreliable in the diagnosis of some forms of double outlet right ventricle. It is superior, once the diagnosis is established, at categorising the variety of double outlet right ventricle present.

When there is true overriding of a great artery, then its assignment to one or other ventricle depends on its precise connexion to those ventricles. This assignment is obtained by projecting the annulus of the overriding valve on to the crest of the ventricular septum and not the line of the long axis of the septum on to the valve (Fig. 9). In practice, this concept is difficult to apply simply because it is a projection not a cross section. We have chosen to define double outlet right ventricle according to the relation of the posterior great artery in the parasternal long axis view or else in precordial short axis scans ${ }^{2}$ when these are possible. These have the advantage of being much more reproducible, but it is clear that the result is to err on the side of conservatism in the diagnosis of double outlet right ventricle as opposed to ven- 


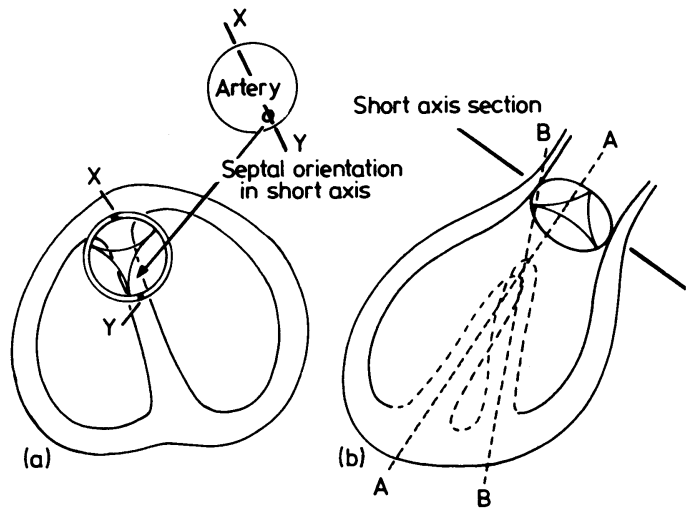

Fig. 9 Diagram showing the assignment of an overriding semilunar valve to the ventricle beneath it. (a) Anatomically, true override is assessed (relative to the chord of a circle, $x y$ ) by projecting the semilunar valve on to the crest of the septum to obtain a short axis pseudosection. (b) The projection of the semilunar valve on to the septal crest is the same as in (a). Projecting the septum on to the semilunar valve is not the correct way to assess override since the result depends on the alignment of the entire length of the septum $(A A, B B)$ rather than on the relation of semilunar valve to septal crest; true override is independent of the septal axis.

triculoarterial concordance or discordance, at least as judged by surgery. This problem, also noted by others, ${ }^{6}$ is not as serious as it at first appears. From the practical point of view, it matters little whether a great artery overrides by $40 \%$ or $60 \%$. What is important is which great artery is overriding, and this is easily established by echocardiography.

These results also illustrate the limitations of division of ventricular septal defects in double outlet right ventricle into four categories of subaortic, subpulmonary, doubly committed, and non-committed or remote types. ${ }^{9-11}$ These categories must, by definition, be mutually exclusive. Yet real difficulties exist in defining how far away is remote and how committed is non-committed. If one arbitrarily states that non-committed defects are within the trabecular or inlet septum then one is immediately faced with trabecular septal defects which are obviously subpulmonary and not therefore non-committed (Fig. 3). Again, one might suppose that if there were no outlet septum the defect would necessarily be doubly committed, yet from the point of view of the communication between the two ventricles that communication may be much closer to one great artery than the other and therefore committed to one, not both, or separated from both by atrioventricular valvar tension apparatus and thus non-committed.

From the echocardiographic standpoint it seems preferable to concentrate on the following four points: (a) Is the outlet septum present? One possibility, which we did encounter in four patients, is that it is present, but hypoplastic. ${ }^{9}(b)$ What forms the roof of the interventricular communication? (c) Where are the atrioventricular valves inserted? In atrioventricular concordance the tricuspid valve is of particular importance, but straddling of the mitral valve ${ }^{32}$ or insertion of its tension apparatus into the floor of the ventricular septal defect, both of which were seen in this series, both create severe problems in diverting left ventricular blood to any great artery via an intraventricular conduit. (d) Which outflow tract is closest to the interventricular communication?

As we have shown, these features are all easily demonstrated by echocardiography. Assessment of the precise sensitivity and specificity obtainable awaits prospective study of a large population of such patients. Nevertheless, these features are of key surgical importance. If the anatomy is such that tensor apparatus of the tricuspid valve lies between the interventricular communication and any great artery, irrespective of whether the defect is-in anatomical terms-subaortic, subpulmonary, doubly committed, or non-committed, it presents the same technical problem with respect to that artery as does any truly remote defect. This kind of problem can arise if the tricuspid valve is inserted either into the underside of the outlet septum (which appears to be particularly common in subpulmonary defects) or into the ventriculoinfundibular fold or the roof of the interventricular defect. It can also occur if the defect extends not only anteriorly but also posteriorly from the central fibrous body, giving rise to what has been already termed a "partially non-committed defect." 22

With regard to surgical considerations, it is important to know whether or not the defect is perimembranous. If it is, the conduction system is in much more jeopardy at the margin of the defect. ${ }^{31}$ Although it is possible to identify perimembranous defects by cross sectional echocardiography when the great arteries are normally connected, this depends on the recognition that the defect is related both to the aortic and to the tricuspid valves, ${ }^{33}$ or else is roofed by mitral and tricuspid valves in continuity. In double outlet right ventricle the relation between these reference points is in any case disturbed. We are therefore uncertain as to the confidence with which the relation of the defect to the intervalvar fibrous skeleton (atrioventricular membranous septum) can be established. This point can readily be determined at the time of open heart surgery without detriment to the patient. What really causes harm is an attempt at definitive repair in infancy when the anatomy is unfavourable. Cross sectional echocardiography should provide the means of reducing the possibility of this kind of error. 
FJM and RHA are supported by the British Heart Foundation and Vandervell and Joseph Levy Foundations respectively. This study was funded in part by the Child Health Research Appeal Trust. This work was carried out while NHS was on sabbatical leave at the Cardiothoracic Institute.

\section{References}

1 Henry WL, Maron BJ, Griffith JM, Redwood DR, Epstein SE Differential diagnosis of anomalies of the great arteries by real time two-dimensional echocardiography. Circulation 1975; 51: 283-91.

2 Henry WL, Maron BJ, Griffith JM. Cross-sectional echocardiography in the diagnosis of congenital heart disease. Circulation 1977; 56: 267-73.

3 Houston AB, Gregory NL, Coleman EN. Two-dimensional sector scanner echocardiography in cyanotic congenital heart disease. Br Heart f 1977; 39: 1076-81.

4 DiSessa TG, Hagan AD, Pope C, Samtoy L, Friedman WF. Two dimensional echocardiographic characteristics of double outlet right ventricle. Am f Cardiol 1979; 44: 1146-54.

5 Hagler DJ, Tajik AJ, Seward JB, Mair DD, Ritter DG. Wideangle two-dimensional echocardiographic profiles of conotruncal abnormalities. Mayo Clin Proc 1980; 55: 73-82.

6 Hagler DJ, Tajik AJ, Seward JB, Mair DD, Ritter DG. Doubleoutlet right ventricle: wide-angle two-dimensional echocardiographic observations. Circulation 1981; 63: 419-28.

7 Sanders SP, Bierman FZ, Williams RG. Conotruncal malformations: diagnosis in infancy using subxiphoid 2-dimensional echocardiography. Am f Cardiol 1982; 50: 1361-7.

8 Hunter S, Smallhorn JF, Sutherland GR. Two-dimensional echocardiography in double outlet right ventricle. In: Anderson RH, Shinebourne EA, Macartney FJ, Tynan M, eds. Paediatric cardiology 5. Edinburgh: Churchill Livingstone, 1983.

9 Lev M, Bharati S, Meng CCL, Liberthson RR, Paul MH, Idriss F. A concept of double-outlet right ventricle. $\mathcal{F}$ Thorac Cardiovasc Surg 1972; 64: 271-81.

10 Zamora R, Moller JH, Edwards JE. Double-outlet right ventricle: anatomic types and associated abnormalities. Chest 1975; 68: 672-7.

11 Wilcox BR, Ho SY, Macartney FJ, Becker AE, Gerlis LM, Anderson RH. Surgical anatomy of double-outlet right ventricle with situs solitus and atrioventricular concordance. $\mathcal{F}$ Thorac Cardiovasc Surg 1981; 82: 405-17.

12 Huhta JC, Smallhorn JF, de Leval MR, Macartney FJ. Tricuspid valve abnormalities in DORV with subpulmonic VSD [Letter]. $\mathcal{F}$ Thorac Cardiovasc Surg 1982; 84: 154-5.

13 Huhta JC, Smallhorn JF, Macartney FJ. Two dimensional echocardiographic diagnosis of situs. Br Heart $\mathcal{f}$ 1982; 48: 97108.

14 Tynan MJ, Becker AE, Macartney FJ, Quero-Jiménez M, Shinebourne EA, Anderson RH. Nomenclature and classification of congenital heart disease. $\mathrm{Br}$ Heart $\mathcal{F}$ 1979; 41: 544-53.

15 Smallhorn JF, Tommasini G, Macartney FJ. Detection and assessment of straddling and overriding atrioventricular valves by two-dimensional echocardiography. Br Heart $\mathcal{f}$ 1981; 46: 254-62.

16 Sutherland GR, Smallhorn JF, Anderson RH, Rigby ML, Hunter S. Atrioventricular discordance; cross-sectional echocardiographic-morphological correlative study. $\mathrm{Br}$ Hear $\mathrm{f}$ 1983; 50: 8-20.

17 Bierman FZ, Williams RG. Prospective diagnosis of d-transposition of the great arteries in neonates by subxiphoid, two-dimensional echocardiography. Circulation 1979; 60: 1496502.

18 Smallhorn JF, de Leval M, Stark J, et al. Isolated anterior mitral cleft. Two dimensional echocardiographic assessment and differentiation from "clefts" associated with atrioventricular septal defect. Br Heart f 1982; 48: 109-16.

19 Gomes MMR, Weidman WH, McGoon DC, Danielson GK. Double-outlet right ventricle with pulmonic stenosis. Surgical considerations and results of operation. Circulation 1971; 43: 889-94.

20 Gomes MMR, Weidman WH, McGoon DC, Danielson GK. Double-outlet right ventricle without pulmonic stenosis. Surgical considerations and results of operation. Circulation 1971; 43 \& 44 (suppl I):31-6.

21 Harvey JC, Sondheimer HM, Williams WG, Olley PM, Trusler GA. Repair of double-outlet right ventricle. $\mathcal{f}$ Thorac Cardiovasc Surg 1977; 73: 611-5.

22 Piccoli G, Pacifico AD, Kirklin JW, Blackstone EH, Kirklin JK, Bargeron LM Jr. Changing results and concepts in the surgical treatment of double outlet right ventricle: analysis of 137 operations in 126 patients. Am $\mathcal{F}$ Cardiol 1983; 52: 549-54.

23 Franks R, Lincoln C. Surgical management of the double outlet right ventricle. In: Anderson RH, Macartney FJ, Shinebourne EA, Tynan M, eds. Paediatric cardiology 5. Edinburgh: Churchill Livingstone, 1983: 441-50.

24 Judson JP, Danielson GK, Puga FJ, Mair DD, McGoon DC. Double outlet right ventricle. Surgical results, 1970-1980. f Thorac Cardiovasc Surg 1983; 85: 32-40.

25 Luber JM, Castaneda AR, Lang P, Norwood WI. Repair of double-outlet right ventricle: early and late results. Circulation 1983; 68 (suppl II): 144-7.

$26 \mathrm{McGoon}$ DC. Left ventricular and biventricular extracardiac conduits. I Thorac Cardiovasc Surg 1976; 72: 7-14.

27 Kirklin JK, Castaneda AR. Surgical correction of double-outlet right ventricle with noncommitted ventricular septal defect. $\mathcal{f}$ Thorac Cardiovasc Surg 1977; 73: 399-403.

28 Moulton AL, de Leval MR, Macartney FJ, Taylor JFN, Stark J. Rastelli procedure for transposition of the great arteries, ventricular septal defect and left ventricular outflow obstruction. Br Heart f 1981; 45: 20-8.

29 Sridaromont S, Feldt RH, Ritter DG, Davis GD, Edwards JE. Double outlet right ventricle: hemodynamic and anatomic correlations. Am $\mathcal{F}$ Cardiol 1976; 38: 85-94.

30 Sridaromont S, Ritter DG, Feldt RH, Davis GD, Edwards JE. Double-outlet right ventricle. Anatomic angiocardiographic correlations. Mayo Clin Proc 1978; 53: 555-77.

31 Anderson RH, Becker AE, Wilcox BR, Macartney FJ, Wilkinson JL. Surgical anatomy of double-outlet right ventricle - a reappraisal. Am f Cardiol 1983; 52: 555-9.

32 Aziz KU, Paul MH, Muster AJ, Idriss FS. Positional abnormalities of atrioventricular valves in transposition of the great arteries including double outlet right ventricle, atrioventricular valve straddling and malattachment. Am $\mathcal{F}$ Cardiol 1979; 44: 1135-45.

33 Sutherland GR, Godman MJ, Smallhorn JF, Guiterras P, Anderson RH, Hunter S. Ventricular septal defects. Two dimensional echocardiographic and morphological correlations. $\mathrm{Br}$ Heart $\mathrm{f}$ 1982; 47: 316-28. 